\title{
AN ANALYSIS OF LATANIA SCALE (HEMIBERLESIA LATANIAE) CRAWLER SETTLEMENT BEHAVIOUR ON KIWIFRUIT LEAVES AND BARK
}

\author{
M.G. HILL ${ }^{1}$ and T. HOLMES ${ }^{2}$ \\ ${ }^{1}$ The New Zealand Institute for Plant \& Food Research Limited, 412 No1. Rd. \\ Te Puke, New Zealand \\ ${ }^{2}$ The New Zealand Institute for Plant \& Food Research Limited, Mount Albert \\ Research Centre, Private Bag 92 169, Auckland 1041, New Zealand
}

Corresponding author: ghill@hortresearch.co.nz.

\begin{abstract}
Time lapse photography was used in the laboratory to observe the settlement behaviour of Hemiberlesia latania crawlers on kiwifruit leaf discs and canes, to the point of construction of the 'white cap'. No differences were detected in cap construction behaviour on Actinidia chinensis 'Hort16A' and A. deliciosa 'Hayward', despite the fact that the insect invariably dies 1-2 weeks after settlement on $A$. chinensis 'Hort16A'. Cap construction was accomplished through regular and alternate circular turning movements from right to left around a point on the substrate, to which the insect is anchored by its stylet. The rate of turn increases to a maximum 2-3 $\mathrm{h}$ after settlement and from that point, declines. At its maximum period of activity, the insect turns through an arc $>360^{\circ}$. The implications of these results for measuring and understanding host selection behaviour by this highly polyphagous insect are discussed. Keywords: armoured scale insects, diaspididae, kiwifruit, latania scale, host plant selection, host plant resistance, feeding behaviour.
\end{abstract}

\section{INTRODUCTION}

Armoured scale insects (Diaspididae) are important pests of agriculture and horticulture (Miller \& Davidson 2005). They are sessile, neotenous insects that are believed to feed primarily on the contents of parenchyma cells or vascular bundle tissue (Heriot 1934; Banks 1990; Sadof \& Neal 1993). Armoured scale insects construct a hard waxy protective cap over their body, which is firmly appressed to the plant substrate upon which they are feeding. The mobile 'crawler' stage hatches from an egg laid by the female insect beneath its scale cap and forces its way out from underneath the scale at a point near to the posterior end of the female. The crawler normally spends a few hours (maximum of about one day) moving around looking for a suitable place to settle, before inserting its stylet into a chosen substrate and constructing its cap. The process of cap construction has been recorded by several authors but has never been studied in detail (Foldi 1990).

The present study utilised digital camera technology and time-lapse photography to study the process of initial 'white cap' formation using Hemiberlesia lataniae Signoret (Diaspididae; Aspidiotini), an important pest of kiwifruit, as a model for aspidiotine armoured scale insects. The behaviour of $H$. lataniae crawler settlement on the canes of two commercial kiwifruit cultivars was studied to see if there was any difference in crawler settlement behaviour on the resistant (Actinidia chinensis Planch 'Hort16A') as opposed to the susceptible (A. deliciosa (A Chev.) C.F.Liang et A.R. Ferguson 'Hayward') cultivars. The results have implications for understanding host selection in this highly polyphagous insect pest, and for determining whether crawler settlement behaviour can be used as a bioassay for detecting resistance to armoured scale insects in plants. 


\section{METHODS}

Hemiberlesia lataniae crawlers were obtained from a colony reared on potatoes ('Desiree') and squash ('Butternut') in a constant environment room $\left(21^{\circ} \mathrm{C}, 70 \% \mathrm{RH}\right)$ at the Plant \& Food Research Te Puke Research Centre. Time lapse photography was used to study $H$. lataniae crawler settlement behaviour on mature Actinidia deliciosa 'Hayward' kiwifruit leaves. About 100 crawlers were brushed onto a 50-mm diameter leaf disc placed on moistened tissue paper inside a 90-mm diameter plastic Petri dish. Photographs of the disc were taken every $90 \mathrm{~s}$ with a Kodak Digital SLR camera using a combination of a reversed enlarging lens and bellows to obtain close-up images of the insects (original images covered approx. $4.5 \times 3.0 \mathrm{~mm}$; these were later cropped to $2.7 \times 2.1 \mathrm{~mm}$ ). A Sunpak portable flash unit with AC power was used for illumination. The experiment was set up in an air conditioned laboratory at $20^{\circ} \mathrm{C}$ at $1400 \mathrm{~h}$ on $10 \mathrm{July}$ 2007 and ran until $0400 \mathrm{~h}$ the following morning. The still images from this experiment were made into a short movie using Magic Pic2Ani (http://www.effectmatrix.com), which was used to observe the basic elements of crawler settlement behaviour.

A second set of time-lapse photographs was taken of $H$. lataniae crawlers settling on A. deliciosa 'Hayward' leaf discs in the same air conditioned laboratory at $20^{\circ} \mathrm{C}$ starting at $1130 \mathrm{~h}$ on 10 December 2007, finishing at $0130 \mathrm{~h}$ on 12 December (total duration $38 \mathrm{~h}$ ). A similar camera setup was used, but the field of view was $8.8 \times 5.9 \mathrm{~mm}$. Pictures were taken every $3.5 \mathrm{~min}$. Ten $H$. lataniae crawlers had settled within the field of view and the settlement behaviour of each was measured by examining the photographs frame-by-frame. The following measurements were made of the settlement behaviour of each insect: (1) the time at which the crawler settled at the spot where it was to spin its cap; (2) the time the crawler began to rotate; (3) the time it stopped its rotation; and (4) the angle in degrees and direction through which the crawler had turned during that rotation. Frame-by-frame observations were continued and measurements of steps (2) to (4) were repeated as the crawler rotated from left-to-right constructing its cap, up to the point where the insect became invisible beneath the white cap it had constructed. At that point, the cap was declared to have been completed. Observations were made on a standard 19 inch $(48 \mathrm{~cm})$ Dell ${ }^{\circledR}$ flat screen computer monitor with $1280 \times 1024$ pixel resolution (244 dots per $\mathrm{cm}$ ). A 10 diopter (ca $3.5 \times$ magnification) Optivisor ${ }^{\circledR}$ headband magnifier was used to magnify the images further, which were manipulated using Microsoft@ Office Picture Manager (11.8161.8221) and ImageJ v1.37, running on Microsoft ${ }^{\circledR}$ Windows $\mathrm{XP}$ version 5.1 (SP3). The observations were used to calculate the time (in $\mathrm{min}$ ) to the onset of cap construction after settlement, the duration of cap construction, the angle of turn and the angular rate of turn of the insect during each rotation. These observations allowed a detailed description of initial cap construction to be made.

A third series of time-lapse photographs were taken between $1730 \mathrm{~h}$ and $0800 \mathrm{~h}$, beginning on the evenings of 20 August 2008 and 29 January, 3 February, 24 February and 28 February 2009. These were of $H$. lataniae crawlers settling on 90-mm long pieces of A. deliciosa 'Hayward' and A. chinensis 'Hort16A' cane (between 10 and $15 \mathrm{~mm}$ diameter) cut from unsprayed vines at the Te Puke Research Centre immediately prior to setting up the experiment. The canes had been produced in the current (2008-09) growing season and were 2-3 months old, with the exception of the August 2008 samples, which were from overwintering canes and were 6-9 months old. The pieces of cane from each kiwifruit cultivar were held adjacent to each other in a $90-\mathrm{mm}$ diameter plastic Petri dish with tap water covering half the canes. Photographs of the insects on the two adjacent cane pieces were taken with a Nikon ${ }^{\circledR}$ D60 using a Sigma ${ }^{\circledR}$ $50-\mathrm{mm}$ macro lens with a field of view of $3.5 \times 2.3 \mathrm{~cm}$. Pictures were taken every $90 \mathrm{~s}$ and stored on a laptop computer using Nikon Camera Control Pro 2 software. The images from these experiments were examined frame-by-frame using the same computer setup as for the previous experiment conducted on A. deliciosa 'Hayward' leaves, but no additional optical magnification aid was used. The following measurements were made: (1) the time at which the crawler settled at the spot where it was to spin its cap; (2) the time the crawler began to rotate; and (3) the time at which a white cap was finished 
(the point at which the crawler was no longer visible to the observer). The number of settled crawlers on each piece of cane was counted in the final frame of each set of photographs. The observations in the third set of experiments were made in a laboratory without air conditioning. Temperature was measured throughout the experiments using an Extech ${ }^{\circledR}$ Instruments data logger (model 42270).

The behaviour of a total of 70 insects was measured in the third experiment and this was used to test for differences in the time (in min) from crawler settlement to (a) the onset of cap formation (i.e. the onset of crawler rotation) and (b) cap completion (the point at which the crawler was no longer visible to the observer). A two-way analysis of variance was carried out with the date of the experiment and kiwifruit cultivar as the main effects using the General Linear Model module with adjusted sums of squares in Minitab® 15. The time to the onset of crawler rotation data were log-transformed prior to the analysis to normalise residuals.

\section{RESULTS \\ Initial observations of crawler cap construction on a leaf disc}

A 1-min time-lapse video showing cap formation behaviour was constructed from the initial set of photographs (http://www.youtube.com/watch?v=395XmUkWVBg). The scale insect crawler begins cap construction by secreting wax from glands on its dorsal abdominal surface, and from the pygidium (the insect's 'tail', comprising the partially fused and heavily sclerotised posterior 4 or 5 abdominal segments). After an initial period of wax extrusion, during which the insect is motionless, it begins to rotate to the left or right, presumably pivoting on its stylet, which is embedded in the plant. Using rapid inand-out movements of its pygidium, the insect shapes the edge of the cap as it rotates, creating a firm edge to the cap. Having rotated in one direction, the insect eventually stops and rotates back in the opposite direction. A perfectly circular cap is formed by this process. The detailed behaviour of six individual insects during cap formation, from the moment at which the pivoting behaviour began up to the point at which the cap was so thick that the insect could no longer be seen, is presented in Figure 1. It shows the direction and angle moved through for each turn. The number of discrete turning motions required to construct the basic cap ranged from seven to 22 (Fig. 1). The time taken to construct the cap was also quite variable, with a mean of $970 \pm 226$ SE min (range 392 to $2065 \mathrm{~min}, \mathrm{n}=10$ ). Features common to all the insects were that the movements to right and left alternated and the angle through which the insect passed at each turn increased up to a maximum that was greater than $360^{\circ}$ (mean maximum rotation $=463 \pm 22^{\circ} \mathrm{SE}$; range $370-590^{\circ}, \mathrm{n}=10$ ). In three of the insects in Figure 1 the angle turned was seen to decline after 2 or 3 turns of $>360^{\circ}$. In the other three insects in Figure 1, the view was obscured by the cap while the insects were turning through $>360^{\circ}$. It would appear that while the exact number of turning motions executed is variable, two or three turning motions of $>360^{\circ}$ are key elements in constructing a perfectly circular cap over the insect.

The relationship between the rate of turn of the insect and the log of time since the commencement of cap formation fitted a 3-parameter Gaussian curve of the form:

$\mathrm{y}=5.22 * \exp \left(-0.5((\mathrm{x}-2.196) / 0.611)^{2}\right)$, adjusted $\mathrm{R}^{2}=0.65$

where $\mathrm{x}$ is $\log$ (time since the onset of cap formation) and $\mathrm{y}$ is the angular rate of turn of the insect in degrees per min (Fig. 2). All coefficients were highly significant $(\mathrm{P}<0.001)$. The rate of turn of the insect increased to a maximum of 5.2 degrees per minute after 157 minutes of cap formation and then rapidly declined (Fig. 2). 

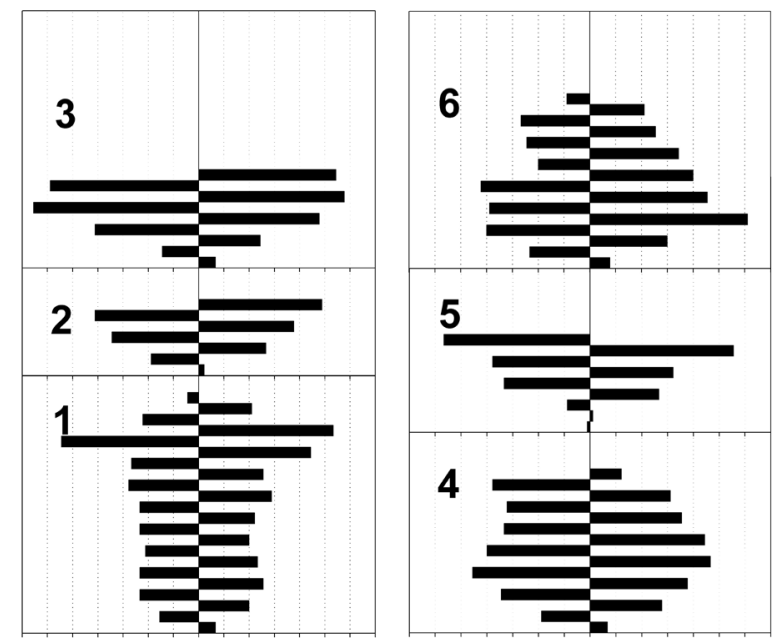

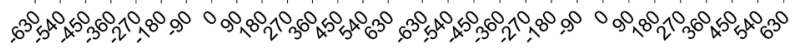

Degrees turned left (negative) or right (positive)

FIGURE 1: The angular movement of six individual Hemiberlesia lataniae crawlers from the onset of cap formation to the point at which the cap was formed and the insect could no longer be observed. The bars show the angle through which the insect turned, and the direction of turn (from the insect's perspective) before stopping and turning back in the opposite direction. The first turning motion is at the bottom of each plot.

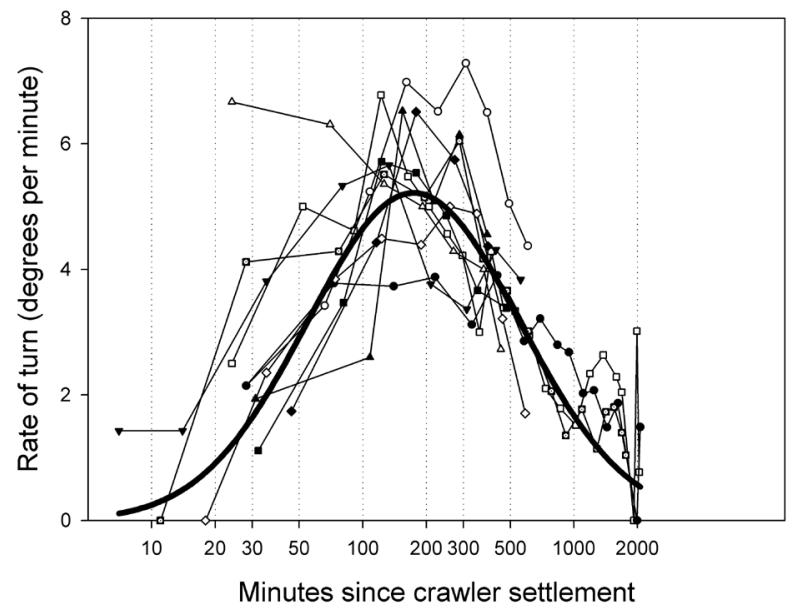

FIGURE 2: The rate of turn (degrees per minute) of 10 Hemiberlesia lataniae crawlers during white cap formation on an Actinidia deliciosa leaf disc. Thick solid line is a 3-parameter Gaussian distribution fitted to the points by nonlinear regression using Sigmaplot 8.0. 


\section{Observations of $\boldsymbol{H}$. lataniae crawler settlement on $A$. chinensis 'Hort16A' and A. deliciosa 'Hayward' bark}

More crawlers settled on 'Hort16A' than on 'Hayward' bark in each of the five replicate experiments (Table 1) $(\mathrm{P}<0.001)$. Analysis of variance of log-transformed data for the time from crawler settlement to the initiation of cap construction showed no difference between the two kiwifruit bark substrates $(\mathrm{P}=0.43)$. However, the time from settlement to the initiation of cap construction approached significance when comparing dates on which the experiment was carried out $(\mathrm{P}=0.055)$. There was no significant difference in the time from initiation of cap construction to its completion between the kiwifruit bark substrates $(\mathrm{P}=0.164)$ nor for time from initiation of cap construction to its completion between the five occasions on which the experiment was carried out $(\mathrm{P}=0.268)$. The average temperature during the experiments varied from 18 to $28^{\circ} \mathrm{C}$. The median time from settlement to the initiation of cap construction (commencement of rotation by the insect) was 49 min (inter-quartile range 21-61 min) on 'Hayward' and $70 \mathrm{~min}$ on 'Hort16A' (inter-quartile range 37-89 $\mathrm{min}$ ). The median time from initiation to the completion of cap construction (the point at which the insect could no longer be seen turning beneath the cap) was 237 min (inter-quartile range 106-209 min) for 'Hayward' and 284 min (inter-quartile range 216-244 $\mathrm{min}$ ) for 'Hort16A'.

TABLE 1: The number of Hemiberlesia lataniae crawlers that successfully completed cap construction on each kiwifruit cultivar on five experimental dates.

\begin{tabular}{lcc}
\hline Experiment & 'Hort16A' & 'Hayward' \\
\hline 20 August 2008 & 12 & 5 \\
29 January 2009 & 42 & 13 \\
3 February 2009 & 64 & 49 \\
24 February 2009 & 32 & 3 \\
28 February 2009 & 8 & 7 \\
Total & 158 & 77 \\
\hline
\end{tabular}

\section{DISCUSSION}

This paper presents the first detailed description of initial cap construction by an armoured scale insect crawler. Previous accounts have described the process in general terms, referring to the initial secretion of wax from pygidial and dorsal glands, the rotation of the crawler body pivoting on the inserted mouthparts and the eventual construction of the cap after 6-10 hours (Dickson 1951; Stoetzel 1976; Foldi 1982, 1990). Foldi (1982), studying cap formation in Aonidiella aurantii Mask. and Lepidosaphes beckii (Newman), stated that the body of the scale becomes hidden by the developing cap after about $4 \mathrm{~h}$, which equates well to the median time observed for cap formation by $H$. lataniae of $4-5 \mathrm{~h}$ in the present study at temperatures ranging from $18-30^{\circ} \mathrm{C}$. Cap formation on the A. deliciosa leaf disc was observed to proceed without pause over a period of $14 \mathrm{~h}$ at $20^{\circ} \mathrm{C}$. Thus, while a basic cap is constructed over a period of about $4 \mathrm{~h}$, the insect continues to develop and improve the cap over a period of at least half a day, without pause. The results also show considerable variation between insects in the time taken to generate the cap. The large difference in the observed times for cap formation between leaf and bark substrates is probably due in large part to the additional magnification (headband magnifier) used to observe cap formation on the leaf disc and the enhanced image quality of the photographs, obtained using the extension bellows in the detailed study of cap formation (the second experiment). The poorer image quality in the photographs of $H$. lataniae settling on bark (third experiment) was used to gain a greater field of view 
and greater depth of field, allowing the camera to observe more scale settling on the curved surface of the canes.

This study has shown for the first time that the angle of turn increases as the cap is formed and that the cap is not fully formed until the crawler has spun through a complete circle. Previous studies have suggested that scale insect crawlers do not complete a full circle, but are restricted to an arc of $270^{\circ}$ to $315^{\circ}$ (Baranyovits 1953; Foldi 1990). However, Dickson (1951) observed that third instar A. aurantii can rotate through an arc of $540^{\circ}$. The present study also shows that the rate of turn of the insect increases with the angle of turn up to about $3 \mathrm{~h}$ after the initiation of cap formation. After the completion of the basic scale cap covering, after 3-4 h, the rate of turn on the insect decreases.

These studies showed no difference in the cap construction behaviour of $H$. lataniae crawlers on the bark of $A$. deliciosa 'Hayward' and A. chinensis 'Hort16A', and that $H$. lataniae crawlers settled more readily on 'Hort16A' than on 'Hayward' bark. In contrast, field studies have shown that 9 days after initial crawler settlement on bark, the number of first instar scale remaining on 'Hort16A' was significantly less than on 'Hayward' (M.G. Hill, unpubl. data). Other studies have shown that H. lataniae cannot complete its development on 'Hort16A', but it can grow successfully on 'Hayward' bark (Hill et al. 2007). Together, these observations support the hypothesis that host plant selection does not occur at the time of armoured scale insect settlement on a putative host plant, but that some antibiotic effect occurring subsequent to crawler settlement and cap construction is causing $H$. lataniae mortality and their subsequent loss from the bark on Hort 16A vines. These and other observations of a physical response mounted by the plant (hypertrophy and hyperplasy of parenchyma and collenchyma cells immediately below the insect (M.G. Hill, unpubl. data)) suggest a mechanism potentially compatible with the gene-for-gene model of plant defences (e.g. Kaloshian 2004; Smith \& Boyko 2007).

Hemiberlesia lataniae is one of the most polyphagous insects in the world, having been recorded feeding on many hundreds of plant species from over 110 families (J. Wu \& B. Normark, University of Massachusetts, pers. comm.; Watson 2005). The finding that $H$. lataniae does not discriminate between a host and non-host plant within the same genus prior to its settling, suggests that its extreme polyphagy may be attributable in part to a propensity to settle on a wide range of plants without discrimination, rather than a superior ability to detect compatible host plants at the time of crawler settlement. However, other important mechanisms are likely to contribute to its polyphagy, such as the presence of avirulence genes (Kaloshian 2004), although these mechanisms remain to be discovered. Finally, the lack of crawler discrimination between suitable hosts and non-hosts precludes crawler settlement behaviour being used as a bioassay for detecting host and non-host plants in this species.

\section{ACKNOWLEDGEMENTS}

This work was partially funded by the New Zealand Foundation for Research, Science and Technology programme (C06X0811): Sustainable Integrated Pest Management in Horticulture. We thank Martin Heffer for assistance with creating the You Tube video.

\section{REFERENCES}

Banks HJ 1990. Physiology and biochemistry. In: Rosen D ed. Armoured scale insects, their biology, natural enemies and control. World Crop Pests. v. 4A. Elsevier, Amsterdam. Pp. 267-274.

Baranyovits F 1953. Some aspects of the biology of armored scale insects. Endeavour 12: 202-209.

Dickson RC 1951. Construction of the scale covering of Aonidiella aurantii. Annales of the Entomological Society of America 44: 596-602.

Foldi I 1982. Etude structurale et experimentale de la formation du bouclier chez les cochenilles diaspines (Hom. Coccoidea Diaspididae). Annales de la Societe Entomologique de France 18 (3): 317-330. 
Foldi I 1990. Moulting and scale cover formation. In: Rosen D ed. Armoured scale insects, their biology, natural enemies and control. World Crop Pests. v.4A. Elsevier, Amsterdam. Pp. 257-265.

Heriot AD 1934. The renewal and replacement of the stylets of sucking insects during each stadium, and the method of penetration. Canadian Journal of Research 11: 602-612.

Hill MG, Mauchline N, Cheng CH, Connolly PG 2007. Measuring the resistance of Actinidia chinensis to armoured scale insects. Acta Horticulturae 753: 685-692.

Kaloshian I 2004. Gene-for-gene disease resistance: bridging insect pest and pathogen defense. Journal of Chemical Ecology 30 (12): 2419-2438.

Miller DR, Davidson JA 2005. Armoured scale insect pests of Trees and Shrubs. Cornell University Press, Ithaca, USA. 442 p.

Sadof CS, Neal JJ 1993. Use of host plant resources by the euonymus scale, Unaspis euonymi (Homoptera: Diaspididae). Annals of the Entomological Society of America 86 (5): 614-620.

Smith CM, Boyko EV 2007. The molecular bases of plant resistance and defense responses to aphid feeding: current status. Entomologia Experimentalis et Applicata $122(1): 1-16$.

Stoetzel MB 1976. Scale-cover formation in the Diaspididae (Homoptera: Coccoidea). Proceedings of the Entomological Society of Washington 78 (3): 323-332.

Watson GW 2005. Diaspididae. In: Ulenberg SA ed. Arthropods of Economic Importance. Zoological Museum and University of Amsterdam. http://nlbif.eti.uva.nl/bis/ diaspididae.php?menuentry=inleiding (retrieved 20/05/2009). 